\title{
An Overview of Islamic Law on Accommodation Leasing in Nglanjaran Hamlet, Sardonoharjo Village, Ngaglik Sub District, Sleman Regency.
}

\author{
M. Roem Syibly \\ Fakultas Ilmu Agama Islam, Universitas Islam Indonesia \\ Email: roemsyibly@gmail.com \\ Dani Arisman \\ Fakultas Ilmu Agama Islam, Universitas Islam Indonesia \\ Email: daniarisman65@gmail.com
}

\begin{abstract}
This study focuses on the contractimplementation tolease an accommodationaccording to Islamic law. This study aims to explain the practices in accommodation leasing in Nglanjaran Hamlet, Sardonoharjo Village, Ngaglik Subdistrict, Sleman Regency, Yogyakarta and to examine the accommodation leasing practices in Nglanjaran Hamlet based on Islamic law. This research used a field research method, with a descriptive analytical approach. The data were collected through observation and interviews. This research shows that the agreement made between the tenant and the accommodation owner was done orally and in writing. This was done in accordance with Islamic law as it fulfills the essential principles and requirements of ijarah. The prices and the period of lease has been determined based on various facilities provided such as physical and non-physical facilities. Meanwhile, disputes that may occur in leasing practices are settled through a negotiation for consensus. To avoid agreement violation, the requirements or any issue related to the lease agreement shall be clearly written to avoid any ambiguity and misunderstanding in the future. In addition, it is suggested that the village apparatus be involved in the arrangement of the lease practice, by way of making general regulations for accommodation leasing in Nglanjaran Hamlet for community comfort in Nglanjaran Hamlet.
\end{abstract}

Keywords: Leasing, Ijarah, Accommodation, Islamic Law 


\title{
Tinjauan Hukum Islam terhadap Praktek Sewa-Menyewa Pemondokan di Dusun Nglanjaran, Desa Sardonoharjo, Kecamatan Ngaglik, Kabupaten Sleman.
}

\author{
M. Roem Syibly \\ Fakultas Ilmu Agama Islam, Universitas Islam Indonesia \\ Dani Arisman \\ Fakultas Ilmu Agama Islam, Universitas Islam Indonesia
}

\begin{abstract}
Abstrak
Penelitian ini fokus pada akad pelaksanaan praktek sewa menyewa pemondokan menurut hukum Islam. Metode penelitian yang digunakan adalah jenis penelitian lapangan, sifat penelitian ini termasuk dalam deskriptif analitik, teknik pengambilan data dengan observasi dan wawancara. Penelitian ini menunjukan bahwa kesepakatan yang terjadi antara penyewa dan pemilik pemomdokan dilakukan secara lisan dan tertulis. Hal ini dilakukan telah sesuai dengan hukum Islam dengan memenuhi rukun dan syarat ijarah. Untuk penentuan harga dan jangka waktu sewa telah ditentukan berdasarkan berbagai fasilitas yang disediakan seperti fasilitas fisik dan non fisiknya. Sedangkan wanprestasi yang terjadi pada praktek sewa menyewa ini diselesaikan dengan secara kekeluargaan. Untukmenghindaripelanggaran terhadap isi perjanjian, maka seharusya persyaratan atau suatu apapun yang berhubungan dengan perjanjian sewa-menyewa ditulis dengan jelas sehingga pada kemudian hari tidak menimbulkan ketidak jelasan dan kesalahpahaman. Dan sebaiknya aparat Dusun juga ikut terlibat dalam pengaturan paraktek sewa menyewa ini, seperti dibuatnya peraturan yang umum untuk pemondokan di Dusun Nglanjaran agar tercipta suasana nyaman dalam bermasyarakat di Dusun Nglanjaran, sehingga nantinya dapat menciptakan suasana aman dan nyaman dalam kehidupan bermasyarakat.
\end{abstract}

Kata Kunci: Sewa-menyewa, Ijarah, Pemondokan, Hukum Islam

\section{INTRODUCTION}

The practice of accommodation leasing is not as easy as it seems. Therefore, it is necessary to know and understand the contents of the agreement made between both parties. The violation of the agreement needs to be re- 
solved by considering various aspects. One party may not terminate or cancel one of the contracts without the consent of the other party. For example, an agreement made between a tenant who has made the down payment for a whole year and the accommodation owner may not be canceled only after occupying the accommodation for only 6 months. The problem of many such cases of contract termination here is whether the accommodation owner will have to return the money for the remaining 6 months or not. Some owners may return part of the money, while some others may not return it at all. ${ }^{1}$

Another problem occurs in the settlement of breach of contract in which the tenant or the rented owner defaults ${ }^{2}$, causing one party to feel disadvantaged. For example, the accommodation owner requires the tenant to move from the leased accommodation long before its due time for renovation. In such case, a question remains whether the accommodation owner will have to return the money to the tenant or not at all. ${ }^{3}$

The practice of accommodation leasing in Ngalanjaran hamlet between the accommodation owners and tenants frequently ends up with various problems causing one party being harmed, thus attracting the researchers to examine accommodation leasing practices in the view of Islamic law.

The problems to consider here is because muamalah requires justice for both parties without harming one party or only benefiting one party and take advantage of the situation.

The problem formulation this study is how is the accommodation leasing practice in Nglanjaran Hamlet, Sardonoharjo Village, Ngaglik Sub District, Sleman Regency, Yogyakarta? And what is the overview of Islamic law on the practice of accommodation leasing in Nglanjaran Hamlet, Sardonoharjo Village, Ngaglik Sub District, Sleman Regency, Yogyakarta?

1 This case was experienced by Hanan, one of the students of the UII (Indonesian Islamic University) from the academic year of 2012. He decided to move from the boarding house he rented although he still have the remaining occupation time for six months. Such cases often occur due to various reasons. (2014)

2 Default is defined as the act of failing to fulfill obligations Subbekti, Pokok Pokok Hukum Perdata (Jakarta, Indonesia: PT Intermasa, 1985), hlm 123; Subbekti, Pokok Pokok Hukum Islam (Jakarta, Indonesia: PT Rineka Cipta, 1992).

3 This case was experienced by Adin. He was one of the students who rented an accomodation in Nglanjaran Hamlet. When his room leaked, the accommodation owner suggested Adin to move to another accommodation. Such cases often occur in other boarding houses. (March, 2017) 
This study aims to explain the practices in accommodation leasing in Nglanjaran Hamlet, Sardonoharjo Village, Ngaglik Subdistrict, Sleman Regency, Yogyakarta and to examine the accommodation leasing practices in Nglanjaran Hamlet based on Islamic law.

\section{LITERATURE STUDY}

\section{Leasing}

Leasing agreements as stipulated in the Civil Code are agreements, where one party binds itself to provide the other party with the benefit of an item for a certain period of time with the payment of a price which the other party is able to pay. ${ }^{4}$ The Great Indonesian Dictionary defines leasing as the use of something by paying rent, or money paid for using or borrowing something. Whereas the General Encyclopedia Dictionary defines renting as the amount of money that must be paid by the tenant for the use of other people's property. ${ }^{5}$

Thus, the lease agreement is an agreement where a party ties itself to submit something or service within a certain period of time, while the other party is obliged to pay a sum of money or objects so that the benefits are received, and everything is done on the basis of their respective agreements - each of which was discussed earlier.

The subject of the leasing agreement includes:

a. The parties that make the agreement, namely the lessee and the lessor. The lessee and the lessor can be an individual, a legal entity represented by an authorized person, someone over certain circumstances using the position/ rights of certain people and person that can be replaced.

b. Objects in trade that can be established and do not conflict with laws and regulations, morality and public order. Article $1549 \mathrm{KUH}$ of Civil Law paragraph 2 states that all types of goods, both immovable and movable, can be leased. ${ }^{6}$

\footnotetext{
4 Abdulkadir Muhammad, Hukum perdata Indonesia (Citra Aditya Bakti, 1990).

5 Kamus besar bahasa Indonesia (Badan Pengembangan dan Pembinaan Bahasa, Kementerian Pendidikan dan Kebudayaan, 2017), hlm 153.

6 Ahmad Rofiq, Hukum Islam di Indonesia (Jakarta: Raja Grafindo Persada, 2003).
} 
Legitimate terms of the lease agreement shall be in accordance with the legal requirements of the agreement, namely:
a. Agree to come into the agreement
b. Capable to make an agreement
c. Regarding certain things
d. A reason that is lawful. ${ }^{7}$

Basically, to lease something to someone, the lessor shall hand over the items to be leased in its best condition. Therefore, before handing over the rental goods, it is necessary to ensure that the goods are in a good and proper condition to be used by the lessee.

In addition to the liability of the lessor, the lessee are also required with 2 main obligations, including:

a. Using the rented goods responsibly (goed huis voder) as if it were his own.

b. Pay rent at predetermined times. Both parties must carry out their respective obligations. The tenants are obliged to pay the rent, while the landlord hands over the goods or objects that are rented in accordance with the agreement.

There must be an end in every agreement that has been agreed upon. The expiration of lease agreement is in accordance with the applicable regulations in Indonesia. The article 1381 of the Civil Code has regulated the following points that cause the expiration of the leasing agreement:

a. End of Leasing Period

The lease term has ended if it is not extended by making a new agreement. The lease agreement that has expired has been null and void by law without the need for a court decision, as stated in article 1570 of the Civil Code.

b. The fulfillment of certain conditions in the leasing agreement.

Overall, a leasing agreement can list the cancellation conditions of the agreement or the time-honored conditions of the agreement if fulfilled.

7 Muhammad, Hukum perdata Indonesia; "Peraturan Daerah Kabupaten Sleman Tahun 2007," Pub. L. No. 8 (2017), http://ditjenpp.kemenkumham.go.id/pembahasan-ruu/78-daftar-peraturandaerah/811-peraturan-daerah-kabupaten-sleman-tahun-2007.html. 
c. Article 1575 of the Civil Code stipulated that the lease agreement did not end because one of the parties died, both the tenant and the landlord. The entire obligation must be continued by the heirs. In addition, the transfer of ownership rights to the leased object did not cause the cancellation of the leasing agreement, except that there had been prior contract and agreement. ${ }^{8}$

\section{Ijarah}

Etymologically, ijarah is a reward or compensation given to someone who has done a job as a reward or repayment for his work.

Terminologically, the author of Mughni Al-Muhtaj of the school of Shafi'i interpreted ijarah as a transaction for the benefits of something that is already known. Another notion from Al-Qaduri of the Hanafi School defined ijarah as a transaction of various benefits (of something) by giving rewards. ${ }^{9}$ The meaning of transactions for benefits or various benefits is to take the benefits of something.

According to as-Sayyid Sabiq, the term rent (ijarah) is derived from the word al ajru which means al iwad (replace). Therefore, al sawab (reward) is called al ajru. According to the meaning of syara ', al-ijarah is a type of contract to take advantage by substitution. ${ }^{10}$

Actually ijarah has been mentioned, discussed and suggested based on the Koran, Sunnah and ijma of the previous scholars.

Ijarah is a form of muamalah relationship and its legal basis has been well regulated in the Koran, the sunnah and the ijtihad of the scholars. Here are some provisions regarding the ijarah law:

"Lodge them [in a section] of where you dwell out of your means and do not harm them in order to oppress them. And if they should be pregnant, then spend on them until they give birth. And if they breastfeed for you, then give them their payment and confer among yourselves in the accept-

8 Muhammad, Hukum perdata Indonesia.

9 Miriam Budiardjo, Dasar-Dasar Ilmu Politik (Gramedia Pustaka Utama, 2003).

10 Teungku Muhammad Hasbi Ash Shiddieqy, Pengantar figh muamalah (Semarang: PT. Pustaka Rizki Putra, 2009) hlm 94. 
able way; but if you are in discord, then there may breastfeed for the father another woman." 11

The other Quranic provision to be used as the basis of the ijarah law is: He said (Shu'aib): He said, "Indeed, I wish to wed you one of these, my two daughters, on [the condition] that you serve me for eight years; but if you complete ten, it will be [as a favor] from you. And I do not wish to put you in difficulty. You will find me, if Allah wills, from among the righteous." 12

The hadith which mentions about ijarah, among them is:

"Having told us Ibrahim ibn Musa from Hisham from Ma'mar from Az Zuhriy from 'Urwah bin Az Zubair from' Aisha radliallahu 'anha: Prophet sallallaahu' alaihi wasallam and Abu Bakr hired a man from the Ad-Dil tribe then from the tribe of 'Abdi bin' Adiy as a guide and who was proficient in mastering the ins and outs of a trip he had previously taken an oath to the family of Al 'Ash bin Wa'il and still embraced the infidel religion of Quraysh. So both of them trusted him in his second journey, and both of them asked him to stop at Tsur's cave after a three-night journey. Then the man went on his second journey during the third evening of prayer, then the two went on their journey and departed with the two of them 'Amir bin Fuhairah and the road guide for the Ad-Diliy tribe. Then the road guide takes the road from the back of the city of Makkah which is along the sea road ". ${ }^{13}$

Basically, there are many hadith provisions and arguments regarding ijarah, but the previous verses and hadith above clearly indicate that ijarah is permissible in Islamic teachings since the above hadith provision mentions that ijarah is well managed in Islamic law. The hadith above also tells to make an immediate payment to reward the person we have ordered or to someone whose energy or ownership has been utilized.

The other legal basis for ijarah is ijma', which is the agreement of the jurists who argue that ijarah (rent) is permissible even though there is a small difference of opinion. ${ }^{14}$

11 At-Talaq (65): 6

12 (Al-Qashash: 27)

13 Alim Sumarno, "Shahih Bukhari : Al-Ijarah (sewa menyewa dan jasa)," diakses 5 Juli 2019, http://www.alimsumarno.com/sunnah/bukhari/id/?book=21.

14 Ahmad Azhar Basyir, Hukum Islam Tentang Wakaf-Ijarah-Syirkah (Alma-Arif, 1987); Khoiruddin Nasution, Islam tentang relasi suami dan isteri (hukum perkawinan I): dilengkapi perbandingan UU negara Muslim (ACAdeMIA, 2004). 


\section{RESEARCH METHOD}

This research is classified as a field research ${ }^{15}$ that aims to collect data, information and real events in the community, in terms of accommodation leasing activities, in Nglanjaran Hamlet, Sardonoharjo Village, Ngaglik Sub District, Sleman Regency, Yogyakarta. ${ }^{16}$

In this study the researcher used a purposive sampling technique which is not based on random, regional or strata, but based on the consideration of some specific goals. ${ }^{17}$

Meanwhile, the data were collected by way of an interview.

\section{Table 1. List of Interviewed Respondents}

\begin{tabular}{|l|l|l|l|l|}
\hline NO & NAME & OWNER/TENANT & OCCUPATION & ADDRESS \\
\hline 1 & Herry Setiawan & Accommodation Owner & Entrepreneur & Sleman \\
\hline 2 & Mirza Ahmad & Tenant & Student & Riau \\
\hline 3 & Yudi & Accommodation Keeper & Entrepreneur & Sleman \\
\hline 4 & Helsa Dian Sari & Tenant & Student & Riau \\
\hline 5 & Siti Shalihah & Accommodation Owner & Teacher & Yogyakarta \\
\hline 6 & Nana Jusolihun & Tenant & Student & Cilacap \\
\hline 7 & Ngatijo & Accommodation Owner & $\begin{array}{l}\text { Retired Civil } \\
\text { Servant }\end{array}$ & Sleman \\
\hline 8 & M. Rezki & Tenant & Student & Sumatra Barat \\
\hline 9 & Basroni & Accommodation Owner & Head of Village & Sleman \\
\hline 10 & Khairul & Tenant & Student & Sulawesi \\
\hline 11 & Supiah & Accommodation Owner & Entrepreneur & Sleman \\
\hline 12 & M. Mujib & Tenant & Student & Kalimantan \\
\hline 13 & Sukari & Accommodation Owner & Entrepreneur & Sleman \\
\hline 14 & Rina Zanuar & Tenant & Student & Malang \\
\hline 15 & Sari & Accommodation Keeper & $\begin{array}{l}\text { Karyawan } \\
\text { Swasta }\end{array}$ & Sleman \\
\hline 16 & $\begin{array}{l}\text { Ananda Fatimah } \\
\text { Zahra }\end{array}$ & Tenant & Student & Riau \\
\hline
\end{tabular}

15 Cholid Narbuko, Metodologi penelitian / Cholid Narbuko, H. Abu Achmadi. --, Cet. 1 (Bumi Aksara, 2013); Kholid Narbuko, Metodologi Penelitian (Indonesia: Bumi Kasara, t.t.).

16 Narbuko, Metodologi penelitian / Cholid Narbuko, H. Abu Achmadi. --.

17 Matthew B. Miles dan A. Michael Huberman, Analisis Data Kualitatif: Buku Sumber Tentang Metode-metode Baru (UI Press, 2009), https:/ / openlibrary.telkomuniversity.ac.id/pustaka/9207/analisisdata-kualitatif-buku-sumber-tentang-metode-metode-baru.html. 


\section{a. Document}

The data were referred by examining written materials such as books, papers, notes, regulations and so on correlated to the research purpose as data sources. This documentation technique was carried out by collecting data through written materials, mainly in the form of archives and books on theoretical opinions, arguments, laws and others, which are related to research problems.

The following are documents that were referred as data source:
a. Map located in Villager's Head office of Nglanjaran.
b. Examples of receipts as proof of lease payments.
c. Photo of accommodation regulation attached on the boarding house walls.

\section{Data Analysis}

This is a qualitative research with inductive analysis. Analysis of qualitative research data according to Miles and Hubermen consists of three stages, namely:
a. Data reduction
b. Data presentation
c. Drawing conclusions and verifying data

Figure 1. Qualitative analysis techniques 18

Qualitative research analysis according to Miles and Hubermen aims to answer qualitative research problems. This is because the qualitative research is based on the research stages arranged systematically, coherently, and naturally (without data manipulation), logically, actually and accountably. In addition, conclusions taken in qualitative research using Miles and Hubermen data analysis can be justified because they have passed the data verification stage. ${ }^{19}$

18 Retrieved from https:/ insanajisubekti.wordpress.com/2013/03/30/analisis-data-kualitatif/, on Thursday March $01^{\text {st }}, 2018$ on 13.58

19 Sahid Rahmad, Analisis Data Penelitian Kualitatif Model Miles Dan Huberman, 2011, https:// id.scribd.com/document/211341201/ Analisis-Data-Penelitian-Kualitatif-Model-Miles-Dan-Huberman. 
In general, Miles and Huberman draw a scheme as presented in the picture above and argue; that the analysis consists of three concurrent activities, namely: data reduction, data presentation and conclusion or data verification.

\section{RESULTS AND DISCUSSION}

Ijarah or referred to as leasing is a form of agreement transaction or contract to use the benefits of an object or service that can be utilized by providing compensation to the owner of the object in the form of wages instead of using the object. ${ }^{20}$

Muamalah transactions of accommodation leasing in Nglanjaran Hamlet are classified in the ijarah, because of the use of accommodation by tenants for temporary housing by obliging the tenants to provide reward in the form of money paid by tenants to the accommodation owners.

The legal basis of ijarah in Islamic law is mubah. In other words, it is permitted if it is in accordance with Islamic syari'ah which is in harmony with the law and the legal requirements of ijarah. Among the arguments about ijarah are:

"Having told us Ibrahim ibn Musa from Hisham from Ma'mar from Az Zuhriy from 'Urwah bin Az Zubair from' Aisha radliallahu 'anha: Prophet sallallaahu' alaihi wasallam and Abu Bakr hired a man from the Ad-Dil tribe then from the tribe of 'Abdi bin' Adiy as a guide and who was proficient in mastering the ins and outs of a trip he had previously taken an oath to the family of Al 'Ash bin Wa'il and still embraced the infidel religion of Quraysh. So both of them trusted him in his second journey, and both of them asked him to stop at Tsur's cave after a three-night journey. Then the man went on his second journey during the third evening of prayer, then the two went on their journey and departed with the two of them 'Amir bin Fuhairah and the road guide for the Ad-Diliy tribe. Then the road guide takes the road from the back of the city of Makkah which is along the sea road." 21

20 Bryan J. Tino;, Perjanjian Sewa Menyewa kios Di Plaza Grand the Central Pekanbaru (Fakultas Hukum, 2018), //lib.unilak.ac.id//index.php?p=show_detail\&id=16764.

21 Retrieved from Online Bukhari Hadith through http://www.alimsumarno.com/sunnah/ bukhari/id/21/al-ijarah-sewa-menyewa-dan-jasa. (09, 10, 2017. 16.30) 
Basically, there are many hadith provisions and arguments regarding ijarah, but the previous verses and hadith above clearly indicate that ijarah is permissible in Islamic teachings since the above hadith provision mentions that ijarah is well managed in Islamic law. The hadith above also tells to make an immediate payment to reward the person we have ordered or to someone whose energy or ownership has been utilized.

The Islamic sharia requires us to fulfill some regulated procedures or rules based on the Quran and Hadith to make leasing transactions.

Leasing or ijarah has several essential principals, as have been outlined by the ulema to determine whether or not the contract is valid. These essential principals referred to are sighat (ijab and qabul), parties that transact (muajjir/lessor, musta'jir/ tenant (lessee)), transaction contract, benefits and wages. ${ }^{22}$

1. Two transacting parties

In the practice of accommodation leasing in Nglanjaran Hamlet, two transacting parties are accommodation owner or accommodation guard as muajjir and students or students' parents as accommodation tenant or musta'jir. Both transacting parties shall be an adult or mumayyiz.

The Islamic law requires the presence of the two transacting parties are mu'ajir (lessor) and musta'jir (tenants/lessee). The ijarah transaction requires the presence of the tenant and the lessor for transaction. The other opinioin may differ by permitting the transaction to be represented by others or by the heir. ${ }^{23}$ These two parties involved in transaction shall be adults who are mentally healthy. ${ }^{24}$

Based on the explanation regarding the essential principles and the legal requirements of ijarah in Islamic law, namely two transacting parties, it is apparent that the leasing practice carried out in Nglanjaran Hamlet has met one of these legitimate conditions and requirements of ijarah.

22 Musthafa Dib AL-Bugha, Buku Pintar Transaksi Syariah (Jakarta: Penerbit Kata, 2010)

23 AL-Bugha, hlm 149.

24 M. Yazid Afandi, Figh muamalah dan implementasinya dalam lembaga keuangan syari'ah: dilengkapi dengan kamus istilah perbankan syariah (Logung Pustaka, 2009), hlm 183. 
2. Transaction agreement

In the practice that took place in Nglanjaran Hamlet, both parties carried out the ijab and kabul verbally. This happened because such agreement had become the custom of the Nglanjaran Hamlet community. The tenant pays rent to the owner or to the accommodation guard by saying that they would like to rent a boarding room owned, and the accommodation owner receives the rent by allowing the tenant to occupy his accommodation with several regulations. This agreement is made after the tenant sends transfer receipt of the payment. In the transaction agreement that occurs both parties not being forced and that they are based on mutual sincerity.

In Islamic law the transaction contract is defined as ijab and kabul. Ijab is a statement from a person who lease his property, which clearly shows the surrender of the benefits of a certain item with a reward. The Ijab may be conducted directly or indirectly. An example of a direct transaction is, "I rent this to you" or with other words. The indirect transaction example is "please use this house after paying the reward" or using other words or statements of the same intention.

Qabul is the saying of the lessee who clearly shows the willingness to accept the benefits of the item. A clear example of Qabul statement includes, "I accept the transaction," or it could be "I rent this" or using other words with the same purpose.

Every person involved in ijarah transaction is free to decide his will or in other words they have free of will. This is so because the ijarah transaction requires both parties to be free from coercion from other people or from any other parties. If later one of the two parties is forced to do ijarah (rent), the agreement will be invalid, as stipulated in the Quranic verse (An-Nisa (4): 29). ${ }^{25}$ 
"O you who have believed, do not consume one another's wealth unjustly but only [in lawful] business by mutual consent. And do not kill yourselves [or one another]. Indeed, Allah is to you ever Merciful." 26

On the basis of the above-mentioned leasing practices in Nglanjaran Hamlet, there is an agreement (ijab) and consent (qabul) with payments agreed upon by both, with no compulsion from any party. Thus, the ijab and the qabul carried out in the Nglanjaran Hamlet have fulfilled the requirements and essential principle of ijarah.

\section{Benefits of objects}

The accommodation for rent in Nglanjaran hamlet is treated as a place to stay for students. When the tenant has paid in full, the accommodation owner hands the room key to the tenant to be used as well as possible. ${ }^{27}$ Afterwards, the owner of the accommodation forbids the tenant from allowing the tenant's female friends to stay in the accommodation. The same also applied for female tenants who are not allowed to stay with a male friend inside the boarding room. In addition, there are many more rules that should not be violated by tenants who are in accordance with Islamic law and applicable law in Indonesia. The tenant who violates such rules can be reprimanded by the accommodation owner or be expelled from the boarding house by the owner. Moreover, when the violation has gone too far like drug abuse, the accommodation owner could have reported the tenant to the authorities.

The object to be leased must be clear, so that later there will be no dispute between the two parties. This can be done by allowing the tenant to observe the accommodation themselves to be clear about

26 An-Nisa (4):29.

27 Dedi Achmad Arifin, "Tinjauan Hukum Islam Terhadap Pelaksanaan Sewa Menyewa Rumah Di Kelurahan Rawa Makmur Kecamatan Palaran" (Universitas Islam Indonesia, 2018); Riska Junefri Susanti, Pelaksanaan Sewa-Menyewa Kamar Kos Ditinjau Dari Hukum Islam (Studi Kasus Di Kelurahan Anduring Kecamatan Kuranji Kota Padang), 2018; Khikmah Nurul Hidayah, “Tinjauan Hukum Islam Terhadap Akad Sewa Menyewa (Ijarah) Dengan Sistem Pembayaran Uang Muka Dalam Penyewaan Kamar Kos (Studi Kasus Di Kembang ArumKelurahan DukuhKecamatan Sidomukti Kota Salatiga)" (other, Fakultas Ekonomi dan Bisnis: Ekonomi Syariah, 2018), http:/ /e-repository.perpus.iainsalatiga.ac.id. 
the properties and items. The owner shall also explain the lease period (validity period) as in a month or a year, and the agreement must explain what benefits are expected. ${ }^{28}$

In Islamic law or sharia, an object that can be benefitted may not be used for something that is forbidden by religion or against the Shari'ah. If it is used for something contrary to syara', the agreement will be illegitimate. For example, it is illegal to rent accommodation if it is used for prostitution and places that violate Islamic law. The point is that the exchange of benefits or rented goods shall be clearly beneficial.

The person who rents out shall be able to deliver goods or objects that are rented completely both physically and based on Islamic law. The lease transaction is invalid if someone rents a car but the car that is rented is lost. This is because the one who rents the object cannot physically deliver his rented object because the car is lost.

The benefits of the object rented by the lessee must be felt by the tenant. In other words, it was illegal to rent a house with a leaked roof making the tenant unable to stay at the house.

It is not permissible to intentionally rent something to collect some of the items that are rented, for example deliberately renting land in which there are trees and fruits to cut down the trees and take the fruits to be sold.

From the ijarah practices that took place in the Hamlet of Nglanjaran, the benefits of the objects rented, namely the accommodation, have been used properly and are not contrary to Islamic law and the applicable law in Indonesia.

On this basis, the practice of accommodation leasing in Nglanjaran Hamlet has been in accordance with the legal requirement. It is in line with the legal conditions regarding the utilization of the rooms rented for occupancy and not for something prohibited in the Islamic religion. Thus, the ijarah practice has been able to meet the requirements and essential principle of ijarah and is considered valid

28 Sabiq, Fiqh Us-Sunnah, hlm 198. 
in Islamic law sharia.

4. Wage

Payment of wages from leases made in Nglanjaran Hamlet uses the Indonesian currency. Prior to the payment of wages, both parties have agreed on the lease price to be paid as well as the tenant's length of stay in the boarding house. The agreement continued with a payment, both made in cash or through transfer system proven by transfer receipts sent to the lessor. The lessee who pay through transfers can use the transfer receipt as legitimate proof of payment. The agreement has mentioned the payment of wages and lease prices agreed upon without anyone feeling forced, which require the presence of the two parties.

In Islamic law, the wages is the reward of benefits controlled by the lease agreement. Wages in the ijarah contract must be clear and must be mutually agreed upon by both parties. The money used for wage payment for an ijarah transaction must be halal or legitimate assets or derived from legitimately. For example, if the wages are in the form of something like drugs, liquor or something that is unclean, the ijarah contract is invalid because the wages are not in accordance with Islamic law.

Since the beginning of the transaction, both parties should know the wages clearly. For example, it is not allowed to rent a house with wages of renovating damaged parts of the house, because the money spent to repair the house is not necessarily balanced with the usual cost of renting a house. The cost of repairing a house can be greater than the price of renting a house or it can be lower.

Based on what was done in the practice of renting accommodation in Nglanjaran hamlet, the payment of wages was in accordance with what was required in Islamic law. Thus, the payment of wages from the accomodation leasing was appropriate and could be considered 
legal in Islamic law.

In addition to the terms and conditions of ijarah described above, Ahmad Azhar Basyir in the Islamic Law Book on Endowments, Ijarah and Syirkah, adds three more conditions, namely as follows:

a. Mu'ajir (the lessor) and Musta'jir (the lessee) shall be an adult, mentally healthy (not crazy or suffering from lost of memory) or is not in custody. Thus, a contract carried out by a crazy person or a child is illegal.

b. Mu'ajir is the owner of a rented item, his guard or a person who accepts a will to act as trustee.

If someone rents a house or other object without the owner's notice, the contract is null and void.

c. The lease period to enjoy the benefits of goods must be clear. ${ }^{29}$

The information related to the lease period shall be made clear when the ijab and kabul of leasing are agreed upon by both parties.

In practice, the accommodation leasing by the Nglanjaran Hamlet community have met the terms and conditions of ijarah stated by Ahmad Azhar Basyir in the Islamic Law Book on Waqf, Ijarah and Syirkah.

The ijarah practice that occurs in the hamlet of Nglanjaran is classified as ijarah a'in. Ijarah ain is rent for the benefit of something that is certain (directly the benefits derived from the goods that are rented). For example, someone says, "I rent this house", when renting out a certain house that is already known by both parties.

The scholars divided ijarah into 2, namely:

1. Ijarah al-'A'yan, which is a lease in the form of objects or animals where people rent to get compensation from tenants.

2. Ijarah al-A'mal, which is an agreement about work or human labor,

29 Basyir, Hukum Islam Tentang Wakaf-Ijarah-Syirkah, hlm 27. 
where the renter gives wages to the party that rents out. ${ }^{30}$

Ahmad Azhar Basyir also divides Ijarah into two, namely:

1. Ijarah al-'Amil means that the object of benefit is from the object or animal that is hired.

2. Ijarah 'at-Asykhash means that the object of rent is human work. ${ }^{31}$

Based on some types of ijarah from various sources and opinions above, it can be concluded that the ijarah contract must explain that the contract and the leased object can be seen and can be used and the object is clear. If the contract and objects of the ijarah object are unclear, the agreement on ijarah shall be canceled based on Sharia.

In the practice of leasing in Nglanjaran Hamlet, there are several problems to note. Some problems that occur in the practice of accommodation leasing in Nglanjaran hamlet such as default or the case when the tenant does not pay rent. Usually, the accommodation owner chooses to deal with it in negotiation for consensus. Islamic law highly recommends such way to solve this problem. However, some accommodation owners sell goods that are left behind by the tenants. Such solution is chosen because the owner of the accommodation cannot contact the tenants. Before selling the goods, the accommodation owner normally provides an injury time for 3 months. However, in case there is no news from the tenants who leave without paying accommodation, the accommodation owner will sell the tenants' properties and the money from the property sale is used as a rent payment during the use of the accommodation. There are also students who move before completion of the lease time. In solving such problems, some owners decide to return the rent with the remaining lease time, while some others do not return the remaining money because according to the accommodation owner, the default is caused by the tenant's own actions for violating agreed contract. If the move is caused by the fault of the accommodation owner such as damage to the accommodation room and others, the rent will be returned.

30 Munir A Munir dan Sudarsono, Dasar-Dasar Agama Islam - (PT. Rineka Cipta, 2013), hlm 426.

31 Basyir, Hukum Islam Tentang Wakaf-Ijarah-Syirkah, hlm 24. 
The practice of accommodation leasing that took place in Nglanjaran Hamlet, all requirements and conditions in the leasing contract had been fulfilled. Although there are problems in the event of a lease, the leasing contract is considered valid because it is contained in the rules of fiqh, which indicates that "basically all forms of muamalah are permitted unless there are arguments that forbid them". There is no form of rent that is prohibited in the Islamic religion. The accommodation is used for stay and applies some regulations that are in accordance with Islamic law to solve any problems that occur. Therefore, the practice of leasing accommodation in Nglanjaran Hamlet is in accordance with Islamic law.

\section{CONCLUSION}

Based on the explanation and analysis on the implementation of leasing practices for accommodation leasing in Nglanjaran Hamlet, Sardonoharjo Village, Ngaglik Sub District, Sleman Regency, Yogyakarta, we can draw the following conclusions:

1. The practice of accommodation leasing in Nglanjaran Hamlet, Sardonoharjo Village, Ngaglik Subdistrict, Sleman Regency, Yogyakarta is commonly conducted through transactions. The transaction generally involves two parties namely the accommodation owners or accommodation guards and students who want to rent the accommodation and their parents. Thus, the ijab and kabul involves the owners or guards of accommodation and students or their parents, with a written proof of lease such as payment receipts or proof of transfer receipt for leasing payment. The rented accommodation is used by tenants, commonly students, as a place of residence. When the students start to occupy the accommodation, the owner will notify them of the rules and sanctions applicable during their occupation in the boarding house verbally. The payment system of the accommodation lease can be in the form of cash or transfers for full payment. No one objected to the applicable payment system at each accommodation in Nglanjara Hamlet, which indicate their willingness. 
2. Based on the overview of Islamic law on accommodation leasing practices in Nglanjaran Hamlet, Sardonoharjo Village, Ngaglik Sub District, Sleman Regency, Yogyakarta, it is done in accordance with Islamic law. In other words, the accommodation leasing in Nglanjaran Hamlet, Sardonoharjo Village, Ngaglik Sub District, Sleman Regency, Yogyakarta, can be seen as legitimate according to Islamic law, since the leasing practice has fulfilled the conditions and requirements of Islamic law such as the existence of two people transacting, the occurrence of oral ijarah agreements between accommodation owners and tenants, the utilization of accommodation as temporary residence by tenant, and the compensation for accommodation leasing agreed upon by both parties.

\section{REFERENCES}

Afandi, M. Yazid. Figh muamalah dan implementasinya dalam lembaga keuangan syari'ah: dilengkapi dengan kamus istilah perbankan syariah. Logung Pustaka, 2009.

Ahmad Rofiq. Hukum Islam di Indonesia. Jakarta: Raja Grafindo Persada, 2003.

AL-Bugha, Musthafa Dib. Buku Pintar Transaksi Syariah. Jakarta: Penerbit Kata, 2010. / /127.0.0.1/index.php?p=show_detail\&id=5234\&keywords=.

Arifin, Dedi Achmad. "Tinjauan Hukum Islam Terhadap Pelaksanaan Sewa Menyewa Rumah Di Kelurahan Rawa Makmur Kecamatan Palaran." Universitas Islam Indonesia, 2018.

Ash Shiddieqy, Teungku Muhammad Hasbi. Pengantar figh muamalah. Semarang: PT. Pustaka Rizki Putra, 2009.

Basyir, Ahmad Azhar. Hukum Islam Tentang Wakaf-Ijarah-Syirkah. Alma-Arif, 1987.

Budiardjo, Miriam. Dasar-Dasar Ilmu Politik. Gramedia Pustaka Utama, 2003.

Hidayah, Khikmah Nurul. “Tinjauan Hukum Islam Terhadap Akad Sewa Menyewa (Ijarah) Dengan Sistem Pembayaran Uang Muka Dalam Penyewaan Kamar Kos (Studi Kasus Di Kembang ArumKelurahan DukuhKecamatan Sidomukti Kota Salatiga)." Other, Fakultas Ekonomi dan 
Bisnis: Ekonomi Syariah, 2018. http:/ / e-repository.perpus.iainsalatiga. ac.id.

Kamus besar bahasa Indonesia. Badan Pengembangan dan Pembinaan Bahasa, Kementerian Pendidikan dan Kebudayaan, 2017.

Miles, Matthew B., dan A. Michael Huberman. Analisis Data Kualitatif: Buku Sumber Tentang Metode-metode Baru. UI Press, 2009. https:/ / openlibrary. telkomuniversity.ac.id/pustaka/9207/analisis-data-kualitatif-bukusumber-tentang-metode-metode-baru.html.

Muhammad, Abdulkadir. Hukum perdata Indonesia. Citra Aditya Bakti, 1990. Munir, Munir A, dan Sudarsono. Dasar-Dasar Agama Islam -. PT. Rineka Cipta, 2013.

Narbuko, Cholid. Metodologi penelitian / Cholid Narbuko, H. Abu Achmadi. --. Cet. 1. Bumi Aksara, 2013.

Narbuko, Kholid. Metodologi Penelitian. Indonesia: Bumi Kasara, t.t.

Nasution, Khoiruddin. Islam tentang relasi suami dan isteri (hukum perkawinan I): dilengkapi perbandingan UU negara Muslim. ACAdeMIA, 2004.

Peraturan Daerah Kabupaten Sleman Tahun 2007, Pub. L. No. 8 (2017). http:/ / ditjenpp.kemenkumham.go.id/pembahasan-ruu/78-daftar-peraturan-daerah/811-peraturan-daerah-kabupaten-sleman-tahun-2007. html.

Rahmad, Sahid. Analisis Data Penelitian Kualitatif Model Miles Dan Huberman, 2011. https://id.scribd.com/document/211341201/Analisis-Data-Penelitian-Kualitatif-Model-Miles-Dan-Huberman.

Sabiq, As-Sayyid. Figh Us-Sunnah: Purification and Prayer. American Trust Publications, 1986.

Subbekti. Pokok Pokok Hukum Islam. Jakarta, Indonesia: PT Rineka Cipta, 1992.

- - - . Pokok Pokok Hukum Perdata. Jakarta, Indonesia: PT Intermasa, 1985.

Sumarno, Alim. "Shahih Bukhari : Al-Ijarah (sewa menyewa dan jasa)." Diakses 5 Juli 2019. http://www.alimsumarno.com/sunnah/bukhari/ $\mathrm{id} /$ ?book=21.

SUSANTI, RISKA JUNEFRI. Pelaksanaan Sewa-Menyewa Kamar Kos Ditinjau Dari Hukum Islam (Studi Kasus Di Kelurahan Anduring Kecamatan Kuranji Kota Padang), 2018. 
Tino;, Bryan J. Perjanjian Sewa Menyewa kios Di Plaza Grand the Central Pekanbaru. Fakultas Hukum, 2018. // lib.unilak.ac.id//index.php?p=show_ detail\&id=16764. 